\title{
A Study of the Key Sustainable Factors of Taiwan's Community Care Centers
}

\author{
Ying-Cheng Hung ${ }^{1}$, Kuei-Chih Chen ${ }^{1, *}$, I-Fei Chen ${ }^{1}$ and Li-Huei Liu ${ }^{2}$ \\ 1 Department of Management Sciences, Tamkang University, New Taipei City 251, Taiwan; \\ aloha@mail.tku.edu.tw (Y.-C.H.); enfatw@gmail.com (I.-F.C.) \\ 2 Charming United Social Association, Taipei City 105, Taiwan; r08848006@gmail.com \\ * Correspondence: coco.a5340@gmail.com
}

check for updates

Citation: Hung, Y.-C.; Chen, K.-C.; Chen, I.-F.; Liu, L.-H. A Study of the Key Sustainable Factors of Taiwan's Community Care Centers.

Sustainability 2022, 14, 1413. https:// doi.org/10.3390/su14031413

Academic Editor:

Haywantee Ramkissoon

Received: 6 December 2021

Accepted: 24 January 2022

Published: 26 January 2022

Publisher's Note: MDPI stays neutral with regard to jurisdictional claims in published maps and institutional affiliations.

Copyright: (C) 2022 by the authors. Licensee MDPI, Basel, Switzerland. This article is an open access article distributed under the terms and conditions of the Creative Commons Attribution (CC BY) license (https:// creativecommons.org/licenses/by/ $4.0 /)$.

\begin{abstract}
In response to the aging society, community care centers have been widely established in Taiwan to take care of the elderly. However, these centers are primarily managed by nonprofit organizations that rely on government subsidies, thus, they lack managerial autonomy. By investigating the key factors influencing the sustainability of community care centers, this study aimed to assist organizations with reducing the risk of managerial uncertainty and promoting the sustainable development of the aging ecosystem. The modified Delphi method and fuzzy analytic hierarchy process were used to construct the key sustainable factors and rank their importance. Four major dimensions, which were management capability, financial and other resource utilization capability, professional care service capability, and customer value creation, along with 21 criteria, were summarized. Management capability had the greatest influence, followed by financial and other resource utilization capability; financial soundness occupied first place in the overall ranking among the criteria. Based on this study's results, it is recommended that when evaluating the units managing the community care centers, their management capability and financial and other resource utilization capability should be evaluated first to reduce the dependence on the government and achieve the goal of sustainability.
\end{abstract}

Keywords: aging in place; community care center; fuzzy analytic hierarchical procedure; key success factors; sustainable management

\section{Introduction}

Good health and well-being are some of the United Nations' Sustainable Development Goals (SDGs) for 2030, which focus on ensuring and promoting healthy lives and well-being among people of all ages [1]. The typical definition of sustainability was "development that meets the needs of the present without compromising the ability of future generations to meet their own needs" by the World Commission on Environment and Development (WCED) [2]. Across all the age groups, the issue of aging has come to be raised by major international organizations, such as the United Nations (UN), the World Health Organization (WHO), and the Organization for Economic Co-management and Development (OECD). Countries around the world have considered prolonging the healthy life expectancy as a significant indicator of aging society development. The WHO adopted The Global Strategy and Action Plan on Aging and Health in May 2016, which encourages countries to develop healthy aging to respond positively to the health needs of the aging population, and promotes the implementation of "aging in place" to create a safe, independent, and comfortable environment for the elderly [3,4]. OECD countries that have entered the stage of an "aging society" earlier have also built a long-term care system based on local communities, such as Japan's integrated community-based care system, which incorporates home health care, medical care, long-term care (LTC), disability care, and support for daily activities [5]; the UK's person-centered NHS Integrated Care Systems, which remove traditional divisions 
between different sectors [6]; and in Germany and Sweden, governments take home-based care into account [7-9].

Taiwan entered the stage of an aging society in 1993 (7\% of the total population aged 65 years or older), and officially has become an aged society in $2018(14 \%)$, and is expected to become a super-aged society in $2025(20 \%)$. In just seven years, Taiwan will transition from an aging society to a super-aged society, and the rate of population aging in Taiwan is among the highest worldwide [10]. In the aging population of Taiwan, more than $80 \%$ of the elderly have a healthy or suboptimal health status. The government should construct communities that could provide elderly services and living support services for healthy elderly. The purpose of establishing these communities includes meeting the elderly needs in life, increasing the elderly healthy life, and promoting active aging. Hence, the Executive Yuan implemented the "Taiwan Healthy Community Six-Star Program" in 2005. Taking community development as the starting point, the program encourages private organizations to set up "community care centers" to offer primary preventive care services, and to carry out initiatives to provide care visits, phone calls, and meal delivery services for the elderly or disabled who rarely leave their homes so that they can move from their homes to the sites to participate in health promotion activities, shared meals, and other diversified services. With the core concept of "local people taking care of local elders," the community care centers became the foundation of the elderly care system in Taiwan and their goals include realizing aging in place, improving care services, and developing a community-based autonomous management model [11,12]. In 2017, the “Ten-year Long-Term Care Plan 2.0" was implemented. One of its goals is to extend the primary preventive care function to promote healthy aging and to design a community care system that can help the elderly age in their homes [13]. With this goal, Long-Term Care 2.0 has incorporated community care centers into the integrated community care system to expand the care capacity. Taiwan's community care centers covered $71.57 \%$ of Taiwanese villages in 2017 [14], indicating that community sites have become a major cornerstone for implementing "aging in place" in Taiwan.

As the elderly population increases and the demand for long-term care rises, OECD countries are facing the problem of financial sustainability. In this regard, countries attempt to control the cost of long-term care by not adding new subsidized services, only subsidizing those with urgent needs, and not increasing the payment rates offered to service providers [15]. In Taiwan, long-term care services also face the problem of financial sustainability. The government implemented the "Ten-Year Long-Term Care Plan" in 2007 and planned to invest TWD 81.7 billion over 10 years to build a long-term care system. However, due to the limited financial resources, the budget for the ten-year long-term care program from 2008 to 2013 ranged from TWD 2.533 billion to TWD 3.238 billion, and from 2010 to 2013, even the second reserve and other related funds had to be used to support the program, resulting in a total implementation budget of only TWD 32.3 billion over 10 years. The severe budget shortages have slowed down the development of long-term care service resources and human resources [13]. In view of this, Taiwan has promoted a "Ten-Year Long-Term Care Plan 2.0" since 2017, using designated taxes as the financial source, including tobacco tax, tobacco health and welfare donations, donations, and bequest tax [16]. However, the government remains under financial pressure with stagnant revenues and declining balances year after year. All of these demonstrate the urgency of developing sustainable strategies to carry out long-term care initiatives.

The main operation model of community care centers in Taiwan is through the government to subsidize non-governmental organizations (NGOs) that cover local offices, schools, community development associations and social groups, etc. Over $90 \%$ of Taiwan's community care centers are managed by nonprofit organizations [17]. These community care centers combine relevant welfare resources to provide services for the elderly. However, for nonprofit organizations to achieve organizational sustainability, they need to evaluate their development strategies and service performances to maintain consistency in their business scope and provide services effectively $[18,19]$. Thus, this study's research question explored 
the key factors of sustainable management of Taiwan's community care centers. On that account, this study provided a comprehensive understanding of the key factors for the sustainable development of community care centers and offers managers and policymakers strategies and management methods to achieve their goals, address uncertainties, and promote the sustainable development of the health and well-being of the elderly in Taiwan.

\section{Literature Review}

Community care centers are important for the Taiwanese government's policy on "aging in place" and community care. Currently, community care centers rely on the government's subsidies, including the costs of facilities and equipment, business expenses, volunteer-related expenses, and supervision fees. However, as the amount increases year after year, community centers are facing an increasingly competitive environment. For a long time, community care centers have been accustomed to receiving financial subsidies to promote organizational service activities in accordance with the government programs and lack the ability to be financially autonomous. Once the funding is reduced or terminated, the community-based services will also be discontinued $[20,21]$. This will make the communitybased care system fragile and will directly affect the health and quality of life of the elderly who are accustomed to going to the care centers.

There are many factors that affect the sustainability of community care centers; Song et al. [22] also indicated that sustainability involved multiple dimensions. Therefore, this study categorized them into several major ones based on the literature, namely, professional care service capability, customer value creation, financial management capability, resource integration capability, and management capability. These factors were mentioned in the literature as being relevant to the sustainability of community care centers, long-term care service providers, and nonprofit organizations.

\subsection{Professional Care Service Capability}

Professional care service capacity is defined as the professional knowledge, service attitude, and related skills that the staff in the community care centers should have. According to a survey conducted by Wang [23], only $44.5 \%$ of the care centers managed by nonprofit organizations in Taiwan employ full-time and part-time staff, which shows that most of the staff are volunteers [23]. Volunteers as the main human resources for site care services can reduce management expenses; however, it is hard for volunteers to provide professional care services and it may result in unstable service quality [20]. Professional staff are important for an organization, and their retention often means providing better services. Previous literature indicated that altruistic motivation, job satisfaction, and leadership of care attendants affect the retention of staff [24-27]. In addition, to enhance the professional skills of staff, it was suggested that education and training help employees gain new knowledge and increase their self-value $[27,28]$; care attendants with professional knowledge offer more proper services and keep them safe [29,30].

\subsection{Customer Value Creation}

Customer value creation refers to the overall evaluation of the services by the customer. Wang [31] suggested that the better the elderly feel about the quality of the service delivered by the community care centers, the more successfully the elderly age in the community [31]. Therefore, it is important to meet the needs of the users for the nonprofit organizations that manage the long-term care service units [32]. The quality of service perceived by the customer is influenced by the care-providing organization's reliability (acting with precision) and responsiveness (providing immediate service) [33]. Francis [34] noted that flexible care that allows care recipients to spend their time freely and a continuity of care that provides follow-up services (contributing to qualitative care) are also important factors for customer value [34]. 


\subsection{Financial Management Capability}

Financial management capability is the ability of community care centers to control, coordinate, and plan funds. Taiwan's community care centers have relied on government funding to operate, and thus, lack financial autonomy. However, with limited resources, the source of funding is a critical factor that influences sustainability. Whether the funding source can attract more resources (e.g., attracting community support, building more partnerships, public relations, legitimacy, and volunteers) and the question of the efficiency of funding are important considerations [35,36]. After obtaining funds, organizations should strictly control their budgets and ensure that the funds are used effectively to respond to organizational goals [37-39]. Financial planning and using strategies also affect the financial performance of organizations [40].

\subsection{Resource Integration Capability}

Resource integration capability is the ability of community care centers to select, integrate, and unify related units and things that can contribute toward development. The Taiwanese Government encourages care centers owned by non-profit organizations to link with external service resources to expand the scale of their care offering and avoid the lack of internal resources [23]. This strategy has also been advocated in several overseas studies; for example, Victor [41] advocated for constructing a community suitable for "aging in place," where no unit in the community can stay aloof from the affair; thus, a strategic alliance should be formed by linking local organizations, resources, information of community members, and the partners who share a common social vision [41-43]. Moreover, maintaining a good relationship with the local government can facilitate the implementation of organizational programs [44]. Therefore, in addition to government policy resources, nonprofit organizations need external professional consultation, medical resources, facilities and equipment, and financial support to develop their community care centers. In order to effectively integrate these resources, organizations should coordinate with others to build a comprehensive resource network [23].

\subsection{Management Capability}

Management capability refers to the ability to effectively plan, manage, and adjust in alignment with the development goals of a community care center. As nonprofit organizations highlight their mission and values, they should select people with a common vision and should also be efficient in the use of resources and responsive to public expectations [45,46]. Managers of nonprofit organizations need to develop business strategies and evaluate effectiveness to achieve the goals of their organizations, for poor management can threaten the sustainability and survival of their organizations [19]. Thus, managers should possess the ability to respond and adapt quickly in a rapidly changing society in order to offer improved services and take responsibility of the society and the environment [47-49].

However, in practice, organizations and the populations they serve have different backgrounds and characteristics. Therefore, based on the above literature, this study aimed to investigate the main factors that influence the sustainability of Taiwan's community care centers via a modified Delphi survey and the fuzzy analytic hierarchy process.

\section{Materials and Methods}

This study used the modified Delphi survey and fuzzy analytic hierarchy process (FAHP) to analyze the key factors that influence the sustainability of Taiwan's community care centers. The research process is shown in Figure 1.

The modified Delphi survey, proposed by Murry and Hommons [50], is similar to the traditional Delphi method in terms of implementation process and statistics. However, it differs in that the first round of the questionnaire replaces expert opinions with the results of an extensive literature search to develop a structured questionnaire. This method saves a lot of time and allows experts to focus on the respective research issue. The traditional analytic hierarchy process can analyze complex assessment questions and convert them into 
a concise hierarchical structure and can identify the relative weighted importance between items to develop a scale [50,51]. In reality, however, human decision making is influenced by subjective perceptions and judgments, and not every element is delineated by clear boundaries; thus, the traditional AHP method cannot be presented properly. Buckley [52] proposed the fuzzy analytic hierarchy process (FAHP) to solve this problem by including the concept of fuzzy theory. This method was used in this study to bring out the reality in a more realistic way [52], for it is a systematic way to conduct decision analysis and compensate for the ambiguity accompanying the comparison of the importance of two elements in the assessment hierarchy carried out by experts.

\begin{tabular}{|l|}
\hline \multicolumn{1}{|c|}{$\underline{\text { Phase 1 }}$} \\
$\frac{\text { Development of dimensions }}{\text { and criteria }}$ \\
1. $\quad$ Literature search and \\
analysis \\
2. Preliminary factor \\
dimensions and criteria
\end{tabular}

\section{Administration: Phase 1}

Modified Delphi survey

\begin{tabular}{|c|}
\hline Phase 2 \\
$\underline{\text { Establishment of a }}$ \\
$\underline{\text { hierarchical structure }}$ \\
1. Administration to \\
expert panel \\
2. Confirm the hierarchy
\end{tabular}

Figure 1. Research flow chart.

Phase 1: Development of dimensions and criteria for the key factors for the sustainability of community care centers

Based on the long-term care management dimensions provided by Evashwick and Riedel [53] and Evashwick [54], as well as the literature and discussions of the research team, the scale summarized the five key sustainability dimensions of professional care service capability, customer value creation, financial management capability, resource integration capability, and management capability. The scale also summarized the five key sustainability dimensions of the 25 sustainability criteria. The contents are described in Table 1. 
Table 1. Elaboration of the evaluation model.

\begin{tabular}{|c|c|c|c|c|}
\hline Goal & Dimension & Guideline & Connotation & Reference \\
\hline \multirow{25}{*}{$\begin{array}{l}\text { Sustainability of } \\
\text { Taiwan's community } \\
\text { care centers }\end{array}$} & \multirow{5}{*}{$\begin{array}{l}\text { Professional care } \\
\text { service capability }\end{array}$} & Local volunteer recruitment & Ability to recruit local volunteers & {$[36,55]$} \\
\hline & & Service motivation & $\begin{array}{l}\text { Enter the service field based on } \\
\text { altruistic motives and maintain a } \\
\text { positive attitude toward service }\end{array}$ & [24-26] \\
\hline & & $\begin{array}{c}\text { Education and training of care } \\
\text { attendants }\end{array}$ & $\begin{array}{c}\text { Continuous training in core } \\
\text { competencies }\end{array}$ & {$[27,28]$} \\
\hline & & Leadership & $\begin{array}{l}\text { Ability to lead groups to achieve their } \\
\text { goals }\end{array}$ & {$[27,56]$} \\
\hline & & Professional knowledge & $\begin{array}{l}\text { Have knowledge and skills related to } \\
\text { caregiving }\end{array}$ & {$[29,30,34]$} \\
\hline & \multirow{5}{*}{$\begin{array}{l}\text { Customer value } \\
\text { creation }\end{array}$} & Customer satisfaction & Meet the expectations of customers & {$[33,57]$} \\
\hline & & Diversified care services & $\begin{array}{l}\text { Diversified approach to service } \\
\text { delivery }\end{array}$ & [58] \\
\hline & & Customized care services & $\begin{array}{l}\text { Provide differentiated services to } \\
\text { meet the needs of customers }\end{array}$ & [34] \\
\hline & & $\begin{array}{l}\text { Good quality of space and } \\
\text { facilities }\end{array}$ & $\begin{array}{l}\text { Provide the appropriate care space } \\
\text { and hardware }\end{array}$ & [59] \\
\hline & & $\begin{array}{l}\text { Follow-up and assistance for } \\
\text { aftercare services }\end{array}$ & Provide continuous extended care & {$[34,60]$} \\
\hline & \multirow{5}{*}{$\begin{array}{l}\text { Financial } \\
\text { management } \\
\text { capability }\end{array}$} & Financial soundness & $\begin{array}{l}\text { Form partnerships with community } \\
\text { groups based on common goals }\end{array}$ & {$[36,37,61]$} \\
\hline & & Proper financial planning & $\begin{array}{l}\text { Ability to make financial } \\
\text { arrangements }\end{array}$ & [40] \\
\hline & & $\begin{array}{l}\text { Achievement of performance } \\
\text { targets }\end{array}$ & $\begin{array}{l}\text { Ability to control the efficiency and } \\
\text { completion of the use of funds }\end{array}$ & {$[37]$} \\
\hline & & $\begin{array}{l}\text { Ability to obtain government } \\
\text { subsidies }\end{array}$ & $\begin{array}{l}\text { Ability to apply for government } \\
\text { subsidies }\end{array}$ & {$[62]$} \\
\hline & & Cost control mechanism & Ability to manage and control costs & {$[38,39]$} \\
\hline & \multirow{5}{*}{$\begin{array}{l}\text { Resource integration } \\
\text { capability }\end{array}$} & $\begin{array}{l}\text { Strategic alliance with } \\
\text { community groups }\end{array}$ & $\begin{array}{l}\text { Form partnerships with community } \\
\text { groups based on common goals }\end{array}$ & {$[36,43]$} \\
\hline & & $\begin{array}{l}\text { Compliance with the local } \\
\text { community development }\end{array}$ & $\begin{array}{l}\text { Ability to integrate the local } \\
\text { characteristics and needs for } \\
\text { implementation }\end{array}$ & {$[63]$} \\
\hline & & Use of government resources & $\begin{array}{l}\text { Ability to understand and integrate } \\
\text { relevant government resources }\end{array}$ & {$[44]$} \\
\hline & & $\begin{array}{l}\text { Connection with the } \\
\text { surrounding community } \\
\text { resources }\end{array}$ & $\begin{array}{l}\text { Ability to ponder over and integrate } \\
\text { that which is available in the } \\
\text { community }\end{array}$ & [41-43] \\
\hline & & $\begin{array}{l}\text { Ability to integrate the } \\
\text { external care service platforms }\end{array}$ & $\begin{array}{l}\text { Ability to connect and link the care } \\
\text { network }\end{array}$ & {$[64,65]$} \\
\hline & \multirow{5}{*}{$\begin{array}{l}\text { Management } \\
\text { capability }\end{array}$} & Sound management system & Establish control standards & {$[45,46]$} \\
\hline & & $\begin{array}{l}\text { Ability to standardize the care } \\
\text { service process }\end{array}$ & $\begin{array}{l}\text { Establish standard operating } \\
\text { procedures }\end{array}$ & [55] \\
\hline & & Ability to rise to the occasion & $\begin{array}{l}\text { Ability to deal with temporary } \\
\text { changes in real time }\end{array}$ & {$[47,48]$} \\
\hline & & Social responsibility & $\begin{array}{l}\text { Comply with ethical standards, meet } \\
\text { unit development vision, and } \\
\text { contribute to the society }\end{array}$ & [49] \\
\hline & & Ability to face competition & $\begin{array}{l}\text { Ability to integrate and manage } \\
\text { resources in a competitive } \\
\text { environment to demonstrate strengths }\end{array}$ & {$[65,66]$} \\
\hline
\end{tabular}

Phase 2: Establishment of a hierarchical structure using the modified Delphi method

To evaluate the uniqueness and professionalism of Taiwan's community care centers, a 15-expert panel familiar with the field of community care centers and services were invited as the subjects to identify the key factors for the sustainability of Taiwan's community 
care centers. The backgrounds of the 15 experts included government agencies, academic research institutions, and practical industry units. The list comprising the details of the expert panel is provided in Appendix A (as shown in Table A1).

The expert panel was required to make a decision on the appropriateness of the criteria in each dimension. If they agreed, they were required to rate the significance of the criteria in relation to the dimensions and assign a value ranging from 0 (very unimportant) to 10 (very important); the "minimum" value of this range indicates the "most conservative perceived value" of the quantitative score of the assessment item and the "maximum" value of this range indicates the "most optimistic perceived value" of the quantitative score of the assessment item. If they disagreed, they were required to check the box to delete or suggest that the criteria should be moved to other appropriate dimensions and give a quantitative score of importance. Finally, any additional or modified criteria proposed for the dimension were also assigned a quantitative significance score.

In order to make the results more convincing and reasonable, a steep slopes analysis was conducted using line graphs, and the threshold of expert consensus was selected from the point where the steepness of the line graph dropped sharply [67]. The revised questionnaire was then administered to the expert panel for a second time until a consensus was reached. After completing the selection of questions based on the results of the steep slopes analysis, the hierarchical structure was revised to devise an FAHP questionnaire.

\section{Phase 3: Application of the FAHP}

The questionnaire design for the expert panel in this study was completed via the adoption of the modified Delphi method. To develop management sustainability for the purposes of this study, FAHP was applied to estimate the weights on criteria and sub-criteria in the following steps [68,69]:

1. Describing the scale of relative importance employed in a pairwise comparison matrix

The item measures were divided into five grades: equally important, slightly important, quite important, extremely important, and absolutely important. These grades were assigned the values of $1,3,5,7$, and 9 . There were four levels between the five measures, and these were assigned the values of 2, 4, 6, and 8 [70]. We employed five triangular fuzzy numbers (TFNs) $(\widetilde{1}, \widetilde{3}, \widetilde{5}, \widetilde{7}, \widetilde{9})$ relative to the corresponding number for expert qualitative assessment in order to capture the vagueness and remove uncertainties (Table 2).

Table 2. Linguistic values and TFNs for the criteria.

\begin{tabular}{cccc}
\hline Linguistic Values & $\begin{array}{c}\text { Triangular Fuzzy } \\
\text { Number }\end{array}$ & $\begin{array}{c}\text { Fuzzy } \\
\text { Number }\end{array}$ & $\begin{array}{c}\text { AHP } \\
\text { Equivalent }\end{array}$ \\
\hline Extreme importance/preference & $(7,9,11)$ & $\widetilde{9}$ & 9 \\
Very strong importance/preference & $(5,7,9)$ & $\widetilde{7}$ & 7 \\
Strong importance/preference & $(3,5,7)$ & $\widetilde{5}$ & 5 \\
Moderate importance/preference & $(1,3,5)$ & $\widetilde{3}$ & 3 \\
Equal importance/preference & $(1,1,3)$ & $\widetilde{1}$ & 1 \\
\hline
\end{tabular}

\section{Constructing a fuzzy comparison matrix}

The experts were asked to make a pairwise comparison for the criteria and sub-criteria using TFNs. The fuzzy comparison matrix $X$ was drawn from the expert's opinions by using the arithmetic mean function for pairwise comparison, as presented in Equation (1).

$$
X=\left[\begin{array}{ccccc}
1 & \widetilde{b}_{12} & \cdots & \cdots & \widetilde{b}_{1 n} \\
\widetilde{b}_{12} & 1 & \cdots & \cdots & \widetilde{b}_{2 n} \\
\cdots & \cdots & \cdots & \cdots & \cdots \\
\cdots & \cdots & \cdots & \cdots & \cdots \\
\widetilde{b}_{n 1} & \widetilde{b}_{n 2} & \cdots & \cdots & 1
\end{array}\right]
$$


where $\widetilde{b}_{i j}=1$ if $i=j$, and $\widetilde{b}_{i j}=(\widetilde{1}, \widetilde{3}, \widetilde{5}, \widetilde{7}, \widetilde{9})$ or $\left(\widetilde{1}^{-1}, \widetilde{3}^{-1}, \widetilde{5}^{-1}, \widetilde{7}^{-1}, \widetilde{9}^{-1}\right)$ if $i \neq j$. To calculate the scores for a pair, a reciprocal score was automatically given to the reverse comparison in the matrix.

3. Conversion of the fuzzy comparison matrix into the crisp comparison matrix

Defuzzification is the conversion of a fuzzy set into an explicit value to represent the characteristics of this set. In this study, the center of area (CA) method was employed for the defuzzification. The procedure for calculating the defuzzification weights is shown in Equation (2).

$$
D F_{i j}=\left[\left(u_{i j}-l_{i j}\right)+\left(m_{i j}-l_{i j}\right)\right] / 3+l_{i j}
$$

\section{Consistency check}

Following the defuzzification and normalization, the CI value (consistency index) was calculated to determine whether the expert panel was consistent regarding the pairwise comparison. $\mathrm{CI} \leq 0.1$ demonstrated that there was consistency, and the weight of defuzzification was used as the basis for ranking each of the dimensions and criteria.

\section{Results}

In this study, 15 questionnaires were sent out in two stages, and all were collected in each of the stages with complete validity. In the first stage, the "Key Factors for the Sustainability of Taiwan's Community Care Centers" questionnaire was developed using the modified Delphi survey. Experts screened the factors for sustainability, determined the dimensions and criteria of the hierarchical analysis framework based on the consensus results, and then ranked the weight of each factor through a fuzzy hierarchical analysis. The following paragraphs give the results of the two-stage analysis:

\subsection{Analysis of the Results of the Modified Delphi Survey}

To establish the analytical framework for the second stage of the hierarchical analysis, the 15 experts were asked to rate and revise the dimensions and criteria for the first round assessment based on the literature review. The steep slopes analysis identified that the threshold of the determinant factor was $\geq 8$, and those below 8 were excluded. After the second round of the questionnaire, a consensus was reached to form the hierarchy used in the second stage. In the first round, the 15 experts omitted four criteria, and revised/added some criteria. This is shown in Table 3. The evaluation result of the second round indicated that the dimension of resource integration capability was below 8 . There was expert consensus stating that the dimension of resource integration capability should combine with the dimension of financial management capability to form the dimension of financial and other resource utilization capability. The final result of the evaluation included 4 dimensions and 21 criteria. 
Table 3. Revised/added criteria for the first round.

\begin{tabular}{|c|c|c|c|}
\hline Dimension & Original Criteria & Revised/Added Criteria & Revised/Added Connotation \\
\hline \multirow{6}{*}{$\begin{array}{l}\text { Professional care service } \\
\text { capability }\end{array}$} & Local volunteer recruitment & $\begin{array}{l}\text { Revised to be classified under } \\
\text { the "resource integration } \\
\text { capability" dimention }\end{array}$ & \\
\hline & Leadership & Empathy of care attendants & $\begin{array}{l}\text { Care attendants can } \\
\text { understand customers' } \\
\text { feelings and needs }\end{array}$ \\
\hline & Professional knowledge & $\begin{array}{l}\text { Professional knowledge of } \\
\text { care attendants }\end{array}$ & $\begin{array}{c}\text { Care attendants have } \\
\text { knowledge and skills related } \\
\text { to caregiving }\end{array}$ \\
\hline & & $\begin{array}{l}\text { Communication skills of } \\
\text { care attendants }\end{array}$ & $\begin{array}{l}\text { Care attendants have the } \\
\text { ability to provide effective } \\
\text { information exchange }\end{array}$ \\
\hline & & $\begin{array}{l}\text { Service attitude of the } \\
\text { service team }\end{array}$ & $\begin{array}{c}\text { The service team display } \\
\text { appropriate attitudes and } \\
\text { behaviors }\end{array}$ \\
\hline & & Hiring local staff & $\begin{array}{l}\text { Recruiting local staff to } \\
\text { provide care service }\end{array}$ \\
\hline \multirow{2}{*}{ Customer value creation } & & $\begin{array}{l}\text { Sense of belongingness and } \\
\text { honor of customers }\end{array}$ & $\begin{array}{c}\text { Customers can feel accepted, } \\
\text { cared for, and valued by the } \\
\text { service }\end{array}$ \\
\hline & & $\begin{array}{l}\text { Feedback and recognition of } \\
\text { customers' family }\end{array}$ & $\begin{array}{l}\text { Getting positive feedback and } \\
\text { affirmation from customers' } \\
\text { families }\end{array}$ \\
\hline \multirow[b]{2}{*}{$\begin{array}{l}\text { Financial management } \\
\text { capability }\end{array}$} & $\begin{array}{l}\text { Achievement of } \\
\text { performance targets }\end{array}$ & Evaluation of service outcome & $\begin{array}{l}\text { Have the examining and } \\
\text { control ability for service } \\
\text { performance }\end{array}$ \\
\hline & $\begin{array}{l}\text { Ability to obtain } \\
\text { government subsidies }\end{array}$ & & $\begin{array}{l}\text { Understand the content of } \\
\text { government policies and have } \\
\text { the ability to apply for } \\
\text { government subsidies }\end{array}$ \\
\hline $\begin{array}{l}\text { Resource integration } \\
\text { capability }\end{array}$ & & $\begin{array}{l}\text { Mutual aid between care } \\
\text { locations }\end{array}$ & $\begin{array}{l}\text { Could provide mutual aid and } \\
\text { exchange resources with other } \\
\text { care locations }\end{array}$ \\
\hline \multirow[b]{2}{*}{ Management capability } & & $\begin{array}{l}\text { Maintaining the original } \\
\text { intention }\end{array}$ & $\begin{array}{l}\text { Maintaining the original } \\
\text { operating philosophy }\end{array}$ \\
\hline & & $\begin{array}{l}\text { Technology-enabled } \\
\text { management }\end{array}$ & $\begin{array}{c}\text { Could make good use of } \\
\text { technological equipment and } \\
\text { digital systems for } \\
\text { management and control }\end{array}$ \\
\hline
\end{tabular}

\subsection{Analysis of the Results of the Fuzzy Analytic Hierarchy Process Scale}

The hierarchy of this study was divided into three levels. The first level concerned the target level: the sustainability of Taiwan's community care centers. The second level concerned the four major dimensions: professional care service capability, customer value creation, financial and other resource utilization capability, and management capability. The third level concerned the 21 criteria (Figure 2).

Power Choice software was used to calculate the weight values and consistency of each criterion. The paired comparison matrix and defuzzification weights are shown in Tables 4-8. The consistency check is shown in Table 9, and the CIs of the criteria in each dimension and between dimensions were less than 0.1 , which were in agreement with the consistency check and showed that this scale was reliable. 
The weight values of each dimension and criterion were ranked in accordance with the defuzzification weights, as shown in Table 10. The weight values of the four dimensions in descending order were as follows: management capability (0.3166), financial and other resource utilization capability $(0.2950)$, professional care service capability $(0.2160)$, and customer value creation (0.1724). The top four weight values of the 21 criteria were financial soundness (C3-1), sound management system (C4-1), proper financial planning (C3-2), and ability to rise to the occasion (C4-3).

Frist level Evaluation goal

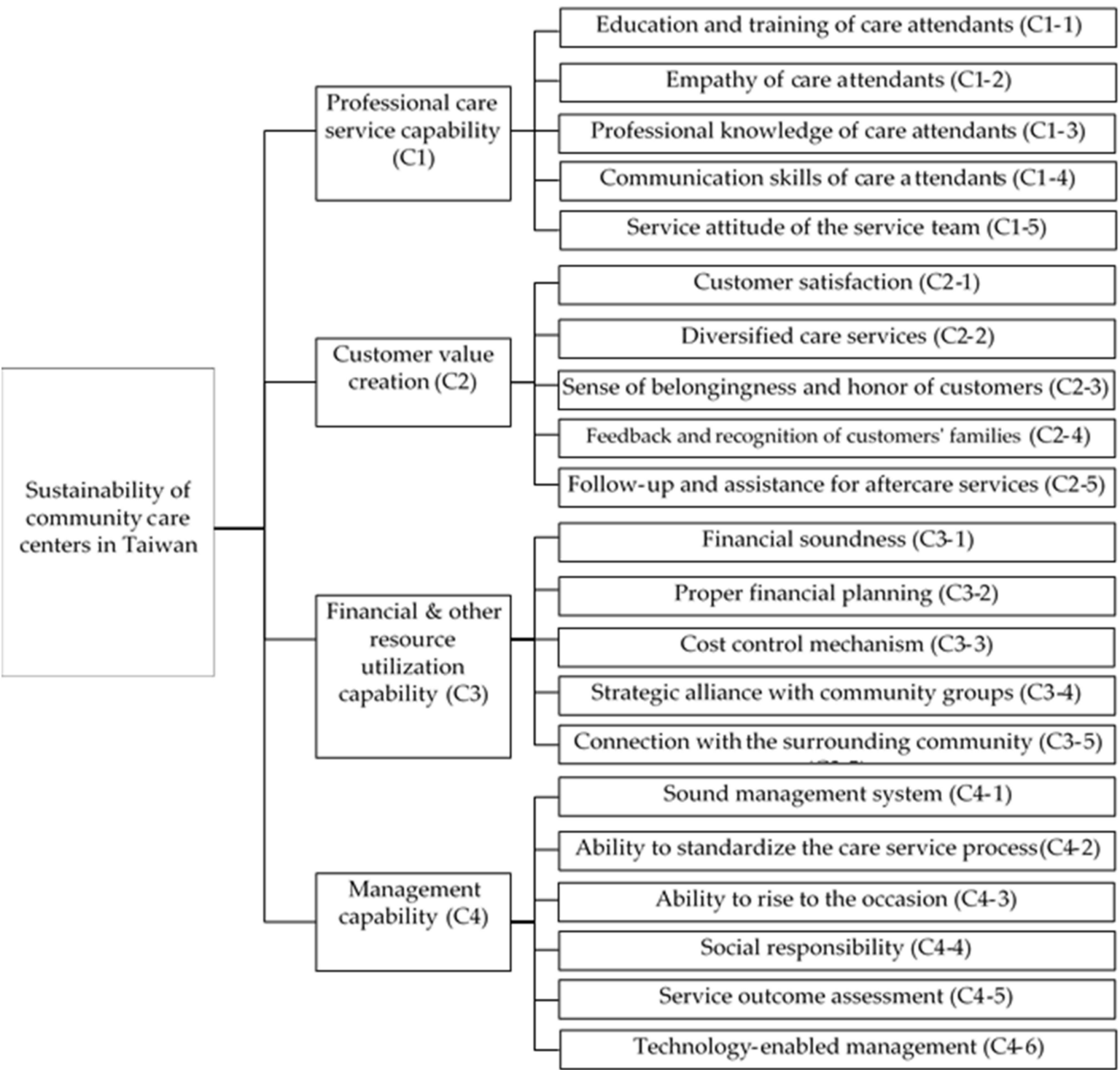

\section{Third level \\ Evaluation criteria}

Figure 2. Modification of the hierarchical structure. 
Table 4. Fuzzy pairwise comparison matrix of the dimensions.

\begin{tabular}{ccccc}
\hline Dimension & $\begin{array}{c}\text { Professional Care } \\
\text { Service Capability }\end{array}$ & $\begin{array}{c}\text { Customer Value } \\
\text { Creation }\end{array}$ & $\begin{array}{c}\text { Financial and Other } \\
\text { Resource Utilization } \\
\text { Capability }\end{array}$ & $\begin{array}{c}\text { Management } \\
\text { Capability }\end{array}$ \\
\hline $\begin{array}{c}\text { Professional care } \\
\text { service capability }\end{array}$ & $(1,1,1)$ & $(0.8247,1.2569,1.8137)$ & $(0.5834,0.7515,1.0071)$ & $(0.5571,0.6605,0.8019)$ \\
\hline $\begin{array}{c}\text { Customer value } \\
\text { creation }\end{array}$ & $(0.5514,0.7956,1.2125)$ & $(1,1,1)$ & $(0.4271,0.5566,0.7260)$ & $(0.4600,0.5581,0.6962)$ \\
\hline $\begin{array}{c}\text { Financial and other } \\
\text { resource utilization } \\
\text { capability }\end{array}$ & $(0.9930,1.3306,1.7141)$ & $(1.3774,1.7967,2.3414)$ & $(1,1,1)$ & $(0.6802,0.9117,1.2699)$ \\
\hline Management capability & $(1.2470,1.5141,1.7952)$ & $(1.4364,1.7918,2.1737)$ & $(0.7875,1.0968,1.4702)$ & $(1,1,1)$ \\
\hline Weights & $(0.2138,0.2156,0.2185)$ & $(0.1705,0.1710,0.1757)$ & $(0.2919,0.2948,0.2984)$ & $(0.3074,0.3186,0.3239)$ \\
\hline DFw & 0.2160 & 0.1724 & 0.2950 & 0.3166 \\
\hline
\end{tabular}

Table 5. Fuzzy pairwise comparison matrix for the professional care service capability criteria.

\begin{tabular}{|c|c|c|c|c|c|}
\hline $\begin{array}{c}\text { Professional Care } \\
\text { Service } \\
\text { Capability }\end{array}$ & $\begin{array}{l}\text { Education and } \\
\text { Training of Care } \\
\text { Attendants }\end{array}$ & $\begin{array}{c}\text { Empathy of Care } \\
\text { Attendants }\end{array}$ & $\begin{array}{c}\text { Professional } \\
\text { Knowledge of } \\
\text { Care Attendants }\end{array}$ & $\begin{array}{l}\text { Communication } \\
\text { Skills of Care } \\
\text { Attendants }\end{array}$ & $\begin{array}{l}\text { Service Attitude } \\
\text { of } \\
\text { the Service Team }\end{array}$ \\
\hline $\begin{array}{l}\text { Education and } \\
\text { training of care } \\
\text { attendants }\end{array}$ & $(1,1,1)$ & $\begin{array}{c}(0.2254,0.2857 \\
0.3837)\end{array}$ & $\begin{array}{c}(0.3571,0.4587 \\
0.6399)\end{array}$ & $\begin{array}{c}(0.2499,0.3113 \\
0.3972)\end{array}$ & $\begin{array}{c}(0.3058,0.4012 \\
0.5306)\end{array}$ \\
\hline $\begin{array}{l}\text { Empathy of care } \\
\text { attendants }\end{array}$ & $\begin{array}{c}(2.6066,3.5005 \\
4.4376)\end{array}$ & $(1,1,1)$ & $\begin{array}{c}(1.1296,1.4805 \\
1.9690)\end{array}$ & $\begin{array}{c}(0.8903,1.1643 \\
1.4524)\end{array}$ & $\begin{array}{c}(0.8561,1.1499 \\
1.4858)\end{array}$ \\
\hline $\begin{array}{l}\text { Professional } \\
\text { knowledge of care } \\
\text { attendants }\end{array}$ & $\begin{array}{c}(1.5629,2.1801 \\
2.8002)\end{array}$ & $\begin{array}{c}(0.5079,0.6754 \\
0.8853)\end{array}$ & $(1,1,1)$ & $(0.5003,0.7057,1)$ & $\begin{array}{c}(0.5783,0.7511 \\
0.9775)\end{array}$ \\
\hline $\begin{array}{l}\text { Communication } \\
\text { skills of care } \\
\text { attendants }\end{array}$ & $\begin{array}{c}(2.5180,3.2123 \\
4.0025)\end{array}$ & $\begin{array}{c}(0.6885,0.8589 \\
1.1232)\end{array}$ & $(1,1.4171,1.9985)$ & $(1,1,1)$ & $\begin{array}{c}(0.7704,1.0473 \\
1.3498)\end{array}$ \\
\hline $\begin{array}{l}\text { Service attitude of } \\
\text { the service team }\end{array}$ & $\begin{array}{c}(1.8846,2.4923 \\
3.2700)\end{array}$ & $\begin{array}{c}(0.6730,0.8696 \\
1.1681)\end{array}$ & $\begin{array}{c}(1.0230,1.3313, \\
1.7291)\end{array}$ & $\begin{array}{c}(0.7408,0.9548, \\
1.2980)\end{array}$ & $(1,1,1)$ \\
\hline Weights & $\begin{array}{c}(0.0811,0.0818, \\
0.0834)\end{array}$ & $\begin{array}{c}(0.2673,0.2712 \\
0.2721)\end{array}$ & $\begin{array}{c}0.1719,0.1758 \\
0.1774)\end{array}$ & $\begin{array}{c}0.2445,0.2448 \\
0.2448)\end{array}$ & $\begin{array}{c}(0.2262,0.2284 \\
0.2289)\end{array}$ \\
\hline DFw & 0.0822 & 0.2702 & 0.1750 & 0.2447 & 0.2278 \\
\hline
\end{tabular}

Table 6. Fuzzy pairwise comparison matrix for the customer value creation criteria.

\begin{tabular}{|c|c|c|c|c|c|}
\hline $\begin{array}{c}\text { Customer Value } \\
\text { Creation }\end{array}$ & $\begin{array}{c}\text { Customer } \\
\text { Satisfaction }\end{array}$ & $\begin{array}{l}\text { Diversified Care } \\
\text { Services }\end{array}$ & $\begin{array}{c}\text { Sense of } \\
\text { Belongingness } \\
\text { and Honor of } \\
\text { Customers }\end{array}$ & $\begin{array}{l}\text { Feedback and } \\
\text { Recognition of } \\
\text { Customers' } \\
\text { Families }\end{array}$ & $\begin{array}{l}\text { Follow-Up and } \\
\text { Assistance for } \\
\text { Aftercare Services }\end{array}$ \\
\hline $\begin{array}{c}\text { Customer } \\
\text { satisfaction }\end{array}$ & $(1,1,1)$ & $\begin{array}{c}(1.6874,2.1255 \\
2.6137)\end{array}$ & $\begin{array}{c}(0.9130,1.1248, \\
1.4053)\end{array}$ & $\begin{array}{c}(1.4110,1.7605 \\
2.1434)\end{array}$ & $\begin{array}{c}(1.3436,1.7393 \\
2.2146)\end{array}$ \\
\hline $\begin{array}{c}\text { Diversified care } \\
\text { services }\end{array}$ & $\begin{array}{c}(0.3826,0.4705 \\
0.5926)\end{array}$ & $(1,1,1)$ & $\begin{array}{c}(0.4633,0.5921, \\
0.7704)\end{array}$ & $\begin{array}{c}(0.7170,0.9911 \\
1.4133)\end{array}$ & $\begin{array}{c}(0.8099,1.1327 \\
1.4634)\end{array}$ \\
\hline $\begin{array}{l}\text { Sense of } \\
\text { belongingness and } \\
\text { honor of customers }\end{array}$ & $\begin{array}{c}(0.7116,0.8891 \\
1.0953)\end{array}$ & $\begin{array}{c}(1.2980,1.6888 \\
2.1585)\end{array}$ & $(1,1,1)$ & $\begin{array}{c}(1.9620,2.3894 \\
2.7955)\end{array}$ & $\begin{array}{c}(1.7322,2.4469 \\
3.3065)\end{array}$ \\
\hline
\end{tabular}


Table 6. Cont.

\begin{tabular}{|c|c|c|c|c|c|}
\hline $\begin{array}{c}\text { Customer Value } \\
\text { Creation }\end{array}$ & $\begin{array}{c}\text { Customer } \\
\text { Satisfaction }\end{array}$ & $\begin{array}{l}\text { Diversified Care } \\
\text { Services }\end{array}$ & $\begin{array}{c}\text { Sense of } \\
\text { Belongingness } \\
\text { and Honor of } \\
\text { Customers }\end{array}$ & $\begin{array}{l}\text { Feedback and } \\
\text { Recognition of } \\
\text { Customers' } \\
\text { Families }\end{array}$ & $\begin{array}{l}\text { Follow-Up and } \\
\text { Assistance for } \\
\text { Aftercare Services }\end{array}$ \\
\hline $\begin{array}{l}\text { Feedback and } \\
\text { recognition of } \\
\text { customers' families }\end{array}$ & $\begin{array}{c}(0.4665,0.5680 \\
0.7087)\end{array}$ & $\begin{array}{c}(0.7076,1.0089 \\
1.3947)\end{array}$ & $\begin{array}{c}(0.3577,0.4185, \\
0.5097)\end{array}$ & $(1,1,1)$ & $\begin{array}{c}(0.6127,0.9021 \\
1.2785)\end{array}$ \\
\hline $\begin{array}{l}\text { Follow-up and } \\
\text { assistance for } \\
\text { aftercare services }\end{array}$ & $\begin{array}{c}(0.4515,0.5750 \\
0.7442)\end{array}$ & $\begin{array}{c}(0.6833,0.8829 \\
1.2347)\end{array}$ & $\begin{array}{c}(0.3024,0.4087 \\
0.5773)\end{array}$ & $\begin{array}{c}(0.7822,1.1085 \\
1.6322)\end{array}$ & $(1,1,1)$ \\
\hline Weights & $\begin{array}{c}(0.2725,0.2806 \\
0.2872)\end{array}$ & $\begin{array}{c}0.1471,0.1493 \\
0.1521)\end{array}$ & $\begin{array}{c}(0.2851,0.2909, \\
0.2914)\end{array}$ & $\begin{array}{c}(0.1371,0.1387 \\
0.1409)\end{array}$ & $\begin{array}{c}0.1373,0.1404 \\
0.1495)\end{array}$ \\
\hline DFw & 0.2801 & 0.1495 & 0.2891 & 0.1389 & 0.1424 \\
\hline
\end{tabular}

Table 7. Fuzzy pairwise comparison matrix for the financial and other resource utilization capability criteria.

\begin{tabular}{|c|c|c|c|c|c|}
\hline $\begin{array}{l}\text { Financial and } \\
\text { Other Resource } \\
\text { Utilization } \\
\text { Capability }\end{array}$ & $\begin{array}{l}\text { Financial } \\
\text { Soundness }\end{array}$ & $\begin{array}{l}\text { Proper Financial } \\
\text { Planning }\end{array}$ & $\begin{array}{l}\text { Cost Control } \\
\text { Mechanism }\end{array}$ & $\begin{array}{c}\text { Strategic Alliance } \\
\text { with Community } \\
\text { Groups }\end{array}$ & $\begin{array}{l}\text { Connection with } \\
\text { the Surrounding } \\
\text { Community }\end{array}$ \\
\hline $\begin{array}{c}\text { Financial } \\
\text { soundness }\end{array}$ & $(1,1,1)$ & $\begin{array}{c}(1.1885,1.7007 \\
2.1837)\end{array}$ & $\begin{array}{c}(1.7811,2.1950, \\
2.5862)\end{array}$ & $\begin{array}{l}(4.2881,5.4203 \\
6.4473)\end{array}$ & $\begin{array}{c}(4.2605,5.4305 \\
6.4805)\end{array}$ \\
\hline $\begin{array}{l}\text { Proper financial } \\
\text { planning }\end{array}$ & $\begin{array}{c}(0.4579,0.5880 \\
0.8414)\end{array}$ & $(1,1,1)$ & $\begin{array}{c}(1.3928,1.8488, \\
2.3401)\end{array}$ & $\begin{array}{c}(3.1384,4.1738 \\
5.2801)\end{array}$ & $\begin{array}{c}(3.2638,4.2823 \\
5.3880)\end{array}$ \\
\hline $\begin{array}{l}\text { Cost control } \\
\text { mechanism }\end{array}$ & $\begin{array}{c}(0.3867,0.4558, \\
0.5614)\end{array}$ & $\begin{array}{c}(0.4273,0.5409 \\
0.7180)\end{array}$ & $(1,1,1)$ & $\begin{array}{c}(2.5370,3.3020 \\
4.0889)\end{array}$ & $\begin{array}{c}(2.5309,3.1708, \\
3.8269)\end{array}$ \\
\hline $\begin{array}{l}\text { Strategic alliance } \\
\text { with community } \\
\text { groups }\end{array}$ & $\begin{array}{c}(0.1551,0.1845, \\
0.2332)\end{array}$ & $\begin{array}{c}(0.1894,0.2396 \\
0.3186)\end{array}$ & $\begin{array}{c}(0.2446,0.3028 \\
0.3942)\end{array}$ & $(1,1,1)$ & $\begin{array}{c}(0.7971,1.1133 \\
1.4986)\end{array}$ \\
\hline $\begin{array}{l}\text { Connection with } \\
\text { the surrounding } \\
\text { community }\end{array}$ & $\begin{array}{c}(0.1543,0.1841, \\
0.2347)\end{array}$ & $\begin{array}{c}(0.1856,0.2335 \\
0.3064)\end{array}$ & $\begin{array}{c}(0.2613,0.3154 \\
0.3951)\end{array}$ & $\begin{array}{c}(0.6673,0.8983 \\
1.2545)\end{array}$ & $(1,1,1)$ \\
\hline Weights & $\begin{array}{c}(0.3867,0.3959, \\
0.3985)\end{array}$ & $\begin{array}{c}(0.2774,0.2818 \\
0.2900)\end{array}$ & $\begin{array}{c}(0.1874,0.1882, \\
0.1928)\end{array}$ & $\begin{array}{c}(0.0671,0.0679 \\
0.0694)\end{array}$ & $\begin{array}{c}(0.0645,0.0660 \\
0.0666)\end{array}$ \\
\hline DFw & 0.3937 & 0.2831 & 0.1895 & 0.0681 & 0.0657 \\
\hline
\end{tabular}

Table 8. Fuzzy pairwise comparison matrix for the management capability criteria.

\begin{tabular}{|c|c|c|c|c|c|c|}
\hline $\begin{array}{c}\text { Management } \\
\text { Capability }\end{array}$ & $\begin{array}{c}\text { Sound } \\
\text { Management } \\
\text { System }\end{array}$ & $\begin{array}{c}\text { Ability to } \\
\text { Standardize } \\
\text { the } \\
\text { Care Service } \\
\text { Process }\end{array}$ & $\begin{array}{l}\text { Ability to Rise } \\
\text { to the Occasion }\end{array}$ & $\begin{array}{c}\text { Social } \\
\text { Responsibility }\end{array}$ & $\begin{array}{c}\text { Service } \\
\text { Outcome } \\
\text { Assessment }\end{array}$ & $\begin{array}{l}\text { Technology- } \\
\text { Enabled } \\
\text { Management }\end{array}$ \\
\hline $\begin{array}{c}\text { Sound } \\
\text { management } \\
\text { system }\end{array}$ & $(1,1,1)$ & $\begin{array}{c}(1.3299,2.0007 \\
2.7019)\end{array}$ & $\begin{array}{c}(1.2020,1.6612 \\
2.3477)\end{array}$ & $\begin{array}{c}(1.5133,2.1932, \\
2.8629)\end{array}$ & $\begin{array}{c}(2.0834,2.7566 \\
3.3596)\end{array}$ & $\begin{array}{c}(2.3313,3.1477 \\
3.9042)\end{array}$ \\
\hline $\begin{array}{l}\text { Ability to } \\
\text { standardize the } \\
\text { care service } \\
\text { process }\end{array}$ & $\begin{array}{c}(0.3701,0.4998 \\
0.7519)\end{array}$ & $(1,1,1)$ & $\begin{array}{c}(0.5763,0.7333 \\
0.9441)\end{array}$ & $\begin{array}{c}(1.2417,1.6856 \\
2.0992)\end{array}$ & $\begin{array}{c}(1.2944,1.7720 \\
2.2636)\end{array}$ & $\begin{array}{c}(2.1913,2.9247, \\
3.7471)\end{array}$ \\
\hline
\end{tabular}


Table 8. Cont.

\begin{tabular}{|c|c|c|c|c|c|c|}
\hline $\begin{array}{l}\text { Management } \\
\text { Capability }\end{array}$ & $\begin{array}{c}\text { Sound } \\
\text { Management } \\
\text { System }\end{array}$ & $\begin{array}{c}\text { Ability to } \\
\text { Standardize } \\
\text { the } \\
\text { Care Service } \\
\text { Process }\end{array}$ & $\begin{array}{l}\text { Ability to Rise } \\
\text { to the Occasion }\end{array}$ & $\begin{array}{c}\text { Social } \\
\text { Responsibility }\end{array}$ & $\begin{array}{c}\text { Service } \\
\text { Outcome } \\
\text { Assessment }\end{array}$ & $\begin{array}{l}\text { Technology- } \\
\text { Enabled } \\
\text { Management }\end{array}$ \\
\hline $\begin{array}{l}\text { Ability to rise } \\
\text { to the occasion }\end{array}$ & $\begin{array}{c}(0.4259,0.6020 \\
0.8319)\end{array}$ & $\begin{array}{c}(1.0592,1.3638, \\
1.7351)\end{array}$ & $(1,1,1)$ & $\begin{array}{c}(2.002,2.6379 \\
3.2813)\end{array}$ & $\begin{array}{c}(2.3643,2.8191 \\
3.2895)\end{array}$ & $\begin{array}{c}(2.6249,3.3470, \\
4.0834)\end{array}$ \\
\hline $\begin{array}{c}\text { Social } \\
\text { responsibility }\end{array}$ & $\begin{array}{c}(0.3493,0.4560 \\
0.6608)\end{array}$ & $\begin{array}{c}(0.4764,0.5933 \\
0.8054)\end{array}$ & $\begin{array}{c}(0.3048,0.3791 \\
0.4996)\end{array}$ & $(1,1,1)$ & $\begin{array}{c}(0.7533,1.1296 \\
1.5819)\end{array}$ & $\begin{array}{c}(1.0581,1.2740, \\
1.8523)\end{array}$ \\
\hline $\begin{array}{l}\text { Service } \\
\text { outcome } \\
\text { assessment }\end{array}$ & $\begin{array}{c}(0.2977,0.3628 \\
0.4800)\end{array}$ & $\begin{array}{c}(0.4418,0.5643 \\
0.7725)\end{array}$ & $\begin{array}{c}(0.3040,0.3547 \\
0.4230)\end{array}$ & $\begin{array}{c}(0.6322,0.8853 \\
1.3274)\end{array}$ & $(1,1,1)$ & $\begin{array}{c}(0.8570,1.2740, \\
1.8523)\end{array}$ \\
\hline $\begin{array}{l}\text { Technology- } \\
\text { enabled } \\
\text { management }\end{array}$ & $\begin{array}{c}(0.2561,0.3177 \\
0.4289)\end{array}$ & $\begin{array}{c}(0.2669,0.3419 \\
0.4563)\end{array}$ & $\begin{array}{c}(0.2449,0.2988 \\
0.3810)\end{array}$ & $\begin{array}{c}(0.4627,0.6356, \\
0.9451)\end{array}$ & $\begin{array}{c}(0.5399,0.7849, \\
1.1669)\end{array}$ & $(1,1,1)$ \\
\hline Weights & $\begin{array}{c}(0.2840,0.2925 \\
0.2945)\end{array}$ & $\begin{array}{c}(0.1791,0.1793 \\
0.1796)\end{array}$ & $\begin{array}{c}(0.2348,0.2439 \\
0.2510)\end{array}$ & $\begin{array}{c}(0.1103,0.1111, \\
0.1156)\end{array}$ & $\begin{array}{c}(0.0972,0.0994 \\
0.1002)\end{array}$ & $\begin{array}{c}(0.0742,0.0756, \\
0.0775)\end{array}$ \\
\hline DFw & 0.2903 & 0.1793 & 0.2432 & 0.1124 & 0.0990 & 0.0758 \\
\hline
\end{tabular}

Table 9. Consistency results.

\begin{tabular}{ccc}
\hline Assessment Indicator & $\begin{array}{c}\text { Intra-Criteria Consistency } \\
\text { within } \\
\text { Dimensions (CI) }\end{array}$ & $\begin{array}{c}\text { Inter-Dimensional } \\
\text { Consistency (CI) }\end{array}$ \\
\hline Professional care service capability & 0.0014 & \\
Customer value creation & 0.0082 & 0.0004 \\
Financial and other resource & 0.0073 & \\
utilization capability & 0.0112 & \\
Management capability & \\
\hline
\end{tabular}

Table 10. Overall priorities of dimensions and criteria.

\begin{tabular}{|c|c|c|c|c|c|c|}
\hline Dimension & Order & Criteria & $\begin{array}{l}\text { Criteria } \\
\text { Weight }\end{array}$ & $\begin{array}{l}\text { Criteria } \\
\text { Ranking }\end{array}$ & $\begin{array}{l}\text { Overall } \\
\text { Weight }\end{array}$ & $\begin{array}{l}\text { Overall } \\
\text { Ranking }\end{array}$ \\
\hline \multirow{5}{*}{$\begin{array}{c}\text { Professional } \\
\text { care service } \\
\text { capability }(\mathrm{C} 1) \\
(0.2160)\end{array}$} & \multirow{5}{*}{3} & $\begin{array}{l}\text { Education and training of care } \\
\text { attendants }(\mathrm{C} 1-1)\end{array}$ & 0.0822 & 5 & 0.0178 & 21 \\
\hline & & $\begin{array}{l}\text { Empathy of care attendants } \\
\text { (C1-2) }\end{array}$ & 0.2702 & 1 & 0.0584 & 5 \\
\hline & & $\begin{array}{c}\text { Professional knowledge of } \\
\text { care attendants (C1-3) }\end{array}$ & 0.1750 & 4 & 0.0378 & 12 \\
\hline & & $\begin{array}{c}\text { Communication skills of care } \\
\text { attendants (C1-4) }\end{array}$ & 0.2447 & 2 & 0.0528 & 8 \\
\hline & & $\begin{array}{l}\text { Service attitude of the service } \\
\text { team (C1-5) }\end{array}$ & 0.2278 & 3 & 0.0492 & 10 \\
\hline
\end{tabular}


Table 10. Cont.

\begin{tabular}{|c|c|c|c|c|c|c|}
\hline Dimension & Order & Criteria & $\begin{array}{l}\text { Criteria } \\
\text { Weight }\end{array}$ & $\begin{array}{l}\text { Criteria } \\
\text { Ranking }\end{array}$ & $\begin{array}{l}\text { Overall } \\
\text { Weight }\end{array}$ & $\begin{array}{l}\text { Overall } \\
\text { Ranking }\end{array}$ \\
\hline \multirow{5}{*}{$\begin{array}{l}\text { Customer value } \\
\text { creation }(\mathrm{C} 2) \\
(0.1724)\end{array}$} & \multirow{5}{*}{4} & Customer satisfaction (C2-1) & 0.2801 & 2 & 0.0483 & 11 \\
\hline & & Diversified care services (C2-2) & 0.1495 & 3 & 0.0258 & 15 \\
\hline & & $\begin{array}{l}\text { Sense of belongingness and } \\
\text { honor of customers (C2-3) }\end{array}$ & 0.2891 & 1 & 0.0499 & 9 \\
\hline & & $\begin{array}{l}\text { Feedback and recognition of } \\
\text { customers' families (C2-4) }\end{array}$ & 0.1389 & 5 & 0.0239 & 18 \\
\hline & & $\begin{array}{l}\text { Follow-up and assistance for } \\
\text { aftercare services (C2-5) }\end{array}$ & 0.1424 & 4 & 0.0246 & 16 \\
\hline \multirow{5}{*}{$\begin{array}{c}\text { Financial and } \\
\text { other resource } \\
\text { utilization } \\
\text { capability (C3) } \\
(0.2950)\end{array}$} & \multirow{5}{*}{2} & Financial soundness (C3-1) & 0.3937 & 1 & 0.1161 & 1 \\
\hline & & $\begin{array}{l}\text { Proper financial planning } \\
\text { (C3-2) }\end{array}$ & 0.2831 & 2 & 0.0835 & 3 \\
\hline & & Cost control mechanism (C3-3) & 0.1895 & 3 & 0.0559 & 7 \\
\hline & & $\begin{array}{l}\text { Strategic alliance with } \\
\text { community groups (C3-4) }\end{array}$ & 0.0681 & 4 & 0.0201 & 19 \\
\hline & & $\begin{array}{l}\text { Connection with the } \\
\text { surrounding community } \\
\text { (C3-5) }\end{array}$ & 0.0657 & 5 & 0.0194 & 20 \\
\hline \multirow{6}{*}{$\begin{array}{l}\text { Management } \\
\text { capability }(\mathrm{C} 4) \\
(0.3166)\end{array}$} & \multirow{6}{*}{1} & $\begin{array}{l}\text { Sound management system } \\
\qquad(\mathrm{C} 4-1)\end{array}$ & 0.2903 & 1 & 0.0919 & 2 \\
\hline & & $\begin{array}{l}\text { Ability to standardize the care } \\
\text { service process }(C 4-2)\end{array}$ & 0.1793 & 3 & 0.0568 & 6 \\
\hline & & $\begin{array}{l}\text { Ability to rise to the occasion } \\
\text { (C4-3) }\end{array}$ & 0.2432 & 2 & 0.0770 & 4 \\
\hline & & Social responsibility (C4-4) & 0.1124 & 4 & 0.0356 & 13 \\
\hline & & $\begin{array}{l}\text { Service outcome assessment } \\
\text { (C4-5) }\end{array}$ & 0.0990 & 5 & 0.0313 & 14 \\
\hline & & $\begin{array}{l}\text { Technology-enabled } \\
\text { management (C4-6) }\end{array}$ & 0.0758 & 6 & 0.0240 & 17 \\
\hline
\end{tabular}

\section{Discussion}

This study examined the key factors that influence the sustainability of Taiwan's community care centers through the modified Delphi survey and fuzzy analytic hierarchy process, where the contribution of each factor was expressed as weight values. The dimensional analysis showed "management capability" to have the highest weight value (0.3166) and to be the main key factor influencing the sustainability of Taiwan's community care centers, followed by "financial and other resource utilization capability" $(0.2950)$. These results slightly differed from the previous literature, which suggested that organizations often use their financial performance to assess their sustainability [71]. In this study, "management capability" had the highest weight, which was probably due to the different factors included in the dimension. The dimension of "financial and other resource utilization capability" also included factors such as the surrounding community resources; thus, this may have diluted the weight from the financial aspect. The "management capability" dimension was multifaceted; therefore, it might be slightly more important than the "financial and other resource utilization capability" to experts. However, the difference in weight values between the two was insignificant, and they were both key factors that influenced the sustainability of Taiwan's community care centers.

Among the sustainability criteria, "financial soundness" ranked first overall, indicating that experts considered the stability of capital control and allocation to be the most 
important factor influencing the sustainability of community care centers. A related criterion was "proper financial planning," which ranked third overall. The results aligned with the previous literature, revealing that, for nonprofit organizations, managers need to contemplate the sustainability of funding sources and answer whether they can catalyze the attraction of more resources. Fundraising efficiency is a crucial factor for assessing the financial performance of NPOs. Moreover, managers of nonprofit organizations with better financial performances have robust strategic planning $[35,36,40]$. In practical experience, Taiwan's community care centers rely on government funding to operate; thus, managers need to estimate and plan based on the limited funds when applying for annual funding, follow the changes taking place in government regulations, make timely adjustments during the management period to address funding changes, and exploit the necessary resources to stabilize the service quality of the sites.

The "sound management system" and the "ability to rise to the occasion" in the dimension of management capability ranked second and fourth in the overall criteria, bringing out the experts' argument that the establishment of management norms and the ability to deal with emergencies promptly are significant factors influencing the sustainability of community care centers. An organization's ability to rise to the occasion also corresponds to the "resilience" of an organization. Organizational resilience is defined as an organization's ability to respond and adapt to sudden disturbances (internal and external) and changes and to reorganize itself so that it can turn challenges into opportunities $[48,72]$. Having organizational resilience helps nonprofit organizations to have the ability to face challenges and provide continually valuable services [48]. This finding also echoes the researcher's practical experience, where, in practice, managers need to make rolling corrections, understand new policies and regulations quickly, and make sound management responses, including adjusting the administrative processes, allocation of human resources, communicating with customers, and developing new service models. These improvement measures allow centers to not only offer customers better services but also enable a sustainable existence in a varied society.

In addition to the use of financial and other resources, past literature suggests that no community member can remain indifferent in an aging society and that linking local organizations, community members' resources, and information through forming a strategic alliance with partners who share a common vision can create a more sophisticated care system [41-43]. This conclusion accords with the findings of the present study, indicating that the cooperation with local organizations and the integration of local resources are conducive to the sustainability of community care centers. Furthermore, the integrated care systems implemented by many governments recently, such as the regionally integrated care system in Japan and the Integrated Care Systems (ICS) in the United Kingdom, are all locally based. They integrate local organizations and resources to create locally tailored care systems, indicating that the integration and connection in place constitute the trends in long-term care. Many community care centers in Taiwan are run by local organizations (such as village offices and local nonprofit organizations), and thus, it is essential to coordinate and cooperate with the surrounding organizations in the community and utilize local resources.

\section{Conclusions}

In response to the rapid aging of Taiwan's population, the government has used community care centers as the foundation of the long-term care system to realize the vision of "aging in place." Nevertheless, a majority of Taiwan's community care centers rely on government subsidies and lack the ability to operate on their own, and their management is challenged by limited resources. The purpose of this study was to identify the key factors responsible for the sustainability of community care centers, which can serve as a reference for policymakers who plan to organize community care centers and government counseling.

Our findings showed "management capability" and "financial and other resource utilization capability" to be the top two dimensions influencing the sustainability of com- 
munity care centers. The criteria of "sound management system" and "ability to rise to the occasion" included in the former, as well as "financial soundness" and "proper financial planning" included in the latter, were recognized as the major assessment criteria in previous studies, as well as by the experts. The results are in agreement with the literature and the researcher's practical experience, indicating that the management capability and financial resources management capability of managers are pivotal for sustainability in the face of a changing society and policy norms.

Based on the results of this study, it is recommended that the government should assess the management capability and financial and other resource utilization capability of community care centers in the first place, such as the soundness of the internal management mechanism and the resilience of the organizers to deal with unexpected situations (e.g., if the virtual sites are forced to close during the pandemic, are there other mechanisms in place to take care of the elders?). With regard to finances, the organizers should also be asked to submit regular budgeting and final accounts reports, and to reduce the subsidy costs year after year. The government can lead the community care centers to create multiple financial sources, have a fixed percentage of self-funding, and reduce dependence on the government in order to achieve the goal of sustainability. In addition, it is suggested that the manager of a community care center must build a high-quality management system for providing stable quality of service. Furthermore, a community care center could cooperate with nearby service sites to reduce the activity costs and plan further appropriate fees for service items.

According to the above, the contributions of this study can be summarized as follows. Several issues of sustainable management of community care centers were explored. This study combined the existing literature with expert opinion to establish an evaluation framework of sustainable management in the field of community care centers. Moreover, the analysis results could provide a valuable reference in the field of community care centers for operations management. Furthermore, the results of this study could allow the government to further understand the key factors regarding the sustainable management of community care centers. The government could establish a high-quality advisory service and evaluation mechanism based on the results of this study. Furthermore, we expect the government to give community care centers more flexibility and autonomy through understanding this study. It could allow the community care centers to reduce their reliance on government grants to maintain sustainability.

However, this study had some limitations. First, this study focused only on the key factors of the sustainability of Taiwan's community care centers. It is suggested that future research or policymakers extend the factors of sustainability to other long-term care service institutions and develop evaluation criteria that are suitable for different elderly health service contents in order to promote the sustainability of the health and well-being of the elderly. Second, this study used the modified Delphi survey and the FAHP to evaluate the key factors that influence the sustainability of Taiwan's community care centers with the help of 15 experts. Using such a panel may have caused the indicators (dimensions or criteria) to produce marginal results. Future researchers could invite more evaluators or experts to reduce the marginal results.

Author Contributions: Conceptualization, Y.-C.H., I.-F.C., and K.-C.C.; methodology, Y.-C.H., I.-F.C., K.-C.C., and L.-H.L.; software, K.-C.C. and L.-H.L.; validation, K.-C.C. and L.-H.L.; formal analysis, K.-C.C. and L.-H.L.; investigation, K.-C.C. and L.-H.L.; resources, K.-C.C.; data curation, K.-C.C. and L.-H.L.; writing-original draft preparation, K.-C.C. and L.-H.L.; writing-review and editing, Y.-C.H., I.-F.C., K.-C.C., and L.-H.L.; visualization, K.-C.C. and L.-H.L.; supervision, Y.-C.H. and I.-F.C.; project administration, K.-C.C. and L.-H.L. All authors have read and agreed to the published version of the manuscript.

Funding: This research received no external funding.

Institutional Review Board Statement: Not applicable.

Informed Consent Statement: Not applicable. 
Data Availability Statement: Not applicable.

Conflicts of Interest: The authors declare no conflict of interest.

\section{Appendix A}

Table A1. List of Experts.

\begin{tabular}{|c|c|c|c|}
\hline No. & Category & $\begin{array}{l}\text { Affiliation } \\
\text { (Position) }\end{array}$ & $\begin{array}{l}\text { Years of } \\
\text { Service }\end{array}$ \\
\hline 1 & \multirow{5}{*}{ Government agencies } & $\begin{array}{l}\text { Social Affairs Bureau of New Taipei City Government } \\
\text { (The Chief of Civil Organizations) }\end{array}$ & 2 \\
\hline 2 & & $\begin{array}{l}\text { New Taipei City Government Health Bureau } \\
\text { (The Officer of Long-Term Care Section) }\end{array}$ & 3 \\
\hline 3 & & $\begin{array}{l}\text { Social Policy Advisor of the Social Bureau } \\
\text { (The Officer of Practical Operation/Management/Execution) }\end{array}$ & 4 \\
\hline 4 & & $\begin{array}{c}\text { New Taipei City Social Bureau Elderly Welfare Division } \\
\text { (The Officer of Assisting Operation/Management of Community } \\
\text { Care Center) }\end{array}$ & 10 \\
\hline 5 & & $\begin{array}{l}\text { Social Affairs Bureau of Taoyuan City Government } \\
\text { (The Officer of Assisting Social Welfare Affairs) }\end{array}$ & 6 \\
\hline 6 & \multirow{5}{*}{$\begin{array}{l}\text { Academic research } \\
\text { institutions }\end{array}$} & $\begin{array}{l}\text { Department of Psychology and Counseling, Taipei City University } \\
\text { (The Educator of Practical Operation/Management/Execution) }\end{array}$ & 10 \\
\hline 7 & & $\begin{array}{c}\text { Department of Social Engineering, Jia'nan University of } \\
\text { Pharmacology } \\
\text { (The Educator of Social Welfare and Services) }\end{array}$ & 10 \\
\hline 8 & & $\begin{array}{c}\text { Department of Health Care and Social Work, Taipei Marine Science } \\
\text { and Technology University } \\
\text { (The Educator of Social Welfare and Services) }\end{array}$ & 15 \\
\hline 9 & & $\begin{array}{l}\text { Department of Social Welfare, Chinese Culture University } \\
\text { (The Educator of Social Welfare and Services) }\end{array}$ & 10 \\
\hline 10 & & $\begin{array}{c}\text { Truth University } \\
\text { (The Educator of Social Welfare and Services) }\end{array}$ & 2 \\
\hline 11 & \multirow{5}{*}{ Practical industry units } & $\begin{array}{l}\text { Changhua County Daai Long Care Service and Care Association } \\
\text { (The Worker of Practical Operation/Management/Execution) }\end{array}$ & 20 \\
\hline 12 & & $\begin{array}{l}\text { New Taipei City Yingge Lake Public Support Center } \\
\text { (The Worker of Practical Operation/Management/Execution) }\end{array}$ & 6 \\
\hline 13 & & $\begin{array}{c}\text { New Taipei City Christian New Hope Church } \\
\text { (The Worker of Practical Operation/Management/Execution) }\end{array}$ & 4 \\
\hline 14 & & $\begin{array}{c}\text { The Eden Social Welfare Foundation established the New Taipei City } \\
\text { Three Gorges Disabled Welfare Service Center } \\
\text { (The Worker of Social Welfare and Services) }\end{array}$ & 4 \\
\hline 15 & & $\begin{array}{l}\text { Taipei Xinyi Social Care Association } \\
\text { (The Worker of Practical Operation/Management/Execution) }\end{array}$ & 5 \\
\hline
\end{tabular}

\section{References}

1. United Nations. United Nations Development Programme. 2015. Available online: https://www.undp.org/sustainabledevelopment-goals (accessed on 5 December 2021).

2. World Commission on Environment and Development. Our Common Future; Oxford University Press: Oxford, UK, 1987.

3. World Health Organization. World Report on Ageing and Health; WHO: Geneva, Switzerland, 2015.

4. World Health Organization. A glossary of terms for community health care and services for older persons. In Ageing and Health Technical Report; WHO Centre for Health Development: Kobe, Japan, 2004.

5. Yu, H.W.; Gong, A.H.; Uemura, H.; Chen, Y.M. Lessons learned from the evolution of long-term care programs in Japan and the implications for Taiwan's long-term care system development. Taiwan J. Public Health 2019, 38, 457-469. 
6. $\quad$ NHS England. NHS Long Term Plan Implementation Framework; NHS England: London, UK, 2019.

7. BMG-Bundesministerium für Gesundheit. Leistungsansprüche der Versicherten ab 1. 2017. Available online: https://www. bundesgesundheitsministerium.de/themen/pflege/pflegeversicherungzahlen-und-fakten.html (accessed on 3 October 2021).

8. OECD. OECD Reviews of Health Care Quality: Sweden 2013: Raising Standards, in OECD Reviews of Health Care Quality. 2013. Available online: https:/ / www.oecd.org/els/health-systems/oecd-reviews-of-health-care-quality-sweden-2013-97892642047 99-en.htm (accessed on 3 October 2021). [CrossRef]

9. Wang, P. The Impact of German Long-Term Care Insurance: 1995-2013. J. Soc. Sci. Philos. 2015, 27, $135-203$.

10. National Development Commission. Population Estimates of the Republic of China (2020-2070); National Development Commission: Dongguan, China, 2020.

11. Executive Yuan. Promoting the six-star program for healthy communities in Taiwan. Community Dev. Q. 2005, 110, 517-526.

12. National Health Administration of the Ministry of Health and Welfare. White Paper on Aging Society (Approved Version); Social and Family Affairs Administration Ministry of Health and Welfare Press: Taipei, Taiwan, 2015.

13. Ministry of Health and Welfare. Ten-Year Long-term Care Plan 2.0 (106-115 Years) (Approved Version); Ministry of Health and Welfare: Taipei, Taiwan, 2016.

14. Department of Social and Family, Ministry of Health and Welfare. Universally Established Community Care and care BASES, Widely Diversified Long-Term Care Service Bases. 2017. Available online: https://dep.mohw.gov.tw/doltc/cp-4170-37558-123 .html (accessed on 4 October 2021).

15. Swartz, K. Searching for a balance of responsibilities: OECD countries' changing elderly assistance policies. Annu. Rev. Public Health 2013, 34, 397-412. [CrossRef]

16. Ministry of Health and Welfare. The Long-Term Care Fund's Financial Plan "Financial Income Based on Expenditure" Is Not in Danger of Bankruptcy. 2019. Available online: https://www.mohw.gov.tw/cp-4252-49616-1.html (accessed on 4 October 2021).

17. Department of Social and Family, Ministry of Health and Welfare. Community Care Service Base Care Portal. 2020. Available online: https: / / ccare.sfaa.gov.tw (accessed on 3 October 2021).

18. Al-Tabbaa, O.; Gadd, K.; Ankrah, S. Excellence models in the non-profit context: Strategies for continuous improvement. Int. J. Qual. Reliab. Manag. 2013, 30, 590-612. [CrossRef]

19. Hatten, M.L. Strategic Management in Not-For-Profit Organizations. Strateg. Manag. J. 1982, 3, 89-104. [CrossRef]

20. Sufen, L. Looking at the development of community care centers for the elderly from the perspective of Peili. Community Dev. $Q$. 2016, 153, 305-317.

21. Chen, Y.J. Strength Perspective: An Analysis of Ageing in Place Care Model in Taiwan Based on Traditional Filial Piety. Ageing Int. 2008, 32, 183-204. [CrossRef]

22. Song, B.; Sun, Q.; Li, Y.; Que, C. Evaluating the sustainability of community-based long-term care programmes: A hybrid multi-criteria decision making approach. Sustainability 2016, 8, 657. [CrossRef]

23. Wang, S.T. The Coordination of Nonprofit Organizations in Community Care Service: A Research for the Community Care Stations. NTU Soc. Work. Rev. 2013, 27, 185-228.

24. Mickus, M.; Luz, C.C.; Hogan, A. Voices from the Front: Recruitment and Retention of Direct Care Workers in Long Term Care Across Michigan. 2004. Available online: https://phinational.org/wp-content/uploads/legacy/clearinghouse/MI_vocices_ from_the_front.pdf (accessed on 3 October 2021).

25. Faul, A.C.; Schapmire, T.J.; D'Ambrosio, J.; Feaster, D.; Oak, C.S.; Farley, A. Promoting sustainability in frontline home care aides: Understanding factors affecting job retention in the home care workforce. Home Health Care Manag. Pract. 2010, 22, 408-416. [CrossRef]

26. Tourangeau, A.; Patterson, E.; Rowe, A.; Saari, M.; Thomson, H.; MacDonald, G.; Cranley, L.; Squires, M. Factors influencing home care nurse intention to remain employed. J. Nurs. Manag. 2014, 22, 1015-1026. [CrossRef] [PubMed]

27. Harvath, T.A.; Swafford, K.; Smith, K.; Miller, L.L.; Volpin, M.; Sexson, K.; White, D.; Young, H.A. Enhancing nursing leadership in long-term care. A review of the literature. Res. Gerontol. Nurs. 2008, 1, 187-196. [CrossRef] [PubMed]

28. Figueiredo, D.; Barbosa, A.; Cruz, J.; Marques, A.; Sousa, L. Empowering staff in dementia long-term care: Towards a more supportive approach to interventions. Educ. Gerontol. 2013, 39, 413-427. [CrossRef]

29. Kusmaul, N. The Content of Education for Direct Caregivers. Educ. Gerontol. 2016, 42, 19-24. [CrossRef]

30. Falk-Huzar, E. The Need for Caregiver Education and Training in the Assisted Living Industry. Adult Learn. 2016, 28, 125-127. [CrossRef]

31. Wang, G.X. Exploration of the Relationship between the Service Delivery Quality of Community Care Stations and Successful Aging: The Moderation of Cognition on Government Role. J. Public Adm. 2016, 50, 77-115.

32. Bryson, J.M.; Gibbons, M.J.; Shaye, G. Enterprise Schemes for Nonprofit Survival, Growth, and Effectiveness. Nonprofit Manag. Leadersh. 2001, 11, 271-288. [CrossRef]

33. Parasuraman, A.; Zeithaml, V.A.; Berry, L.L. A conceptual model of service quality and its implications for future research. J. Mark. 1985, 49, 41-50. [CrossRef]

34. Francis, J.; Netten, A. Quality in Home Care: CliSent and Provider Views. 2003. Available online: https://www.pssru.ac.uk/ pub/dp2017.pdf (accessed on 4 October 2021).

35. Ritchie, W.J.; Kolodinsky, R.W. Nonprofit Organization Financial Performance Measurement: An Evaluation of New and Existing Financial Performance Measures. Nonprofit Manag. Leadersh. 2003, 13, 367-381. [CrossRef] 
36. Kearns, K.P.; Bell, D.; Deem, B.; McShane, L. How Nonprofit Leaders Evaluate Funding Sources. Nonprofit Volunt. Sect. Q. 2012, 43, 121-143. [CrossRef]

37. Gaitonde, R.; Muraleedharan, V.R.; Sebastian, M.S.; Hurtig, A.K. Accountability in the health system of Tamil Nadu, India: Exploring its multiple meanings. Health Res. Policy Syst. 2019, 17, 44. [CrossRef] [PubMed]

38. Nouri, H.; Parker, R.J. The relationship between budget participation and job performance: The roles of budget adequacy and organizational commitment. Account. Organ. Soc. 1998, 23, 467-483. [CrossRef]

39. Luft, J.; Shields, M.D. Mapping management accounting: Graphics and guidelines for theory-consistent empirical research. Account. Organ. Soc. 2003, 28, 169-249. [CrossRef]

40. Brown, W.A. Exploring the Association Between Board and Organizational Performance in Nonprofit Organizations. Nonprofit Manag. Leadersh. 2005, 15, 317-339. [CrossRef]

41. Victor, C.R. Community Care and Older People; Nelson Thornes Limited: Cheltenham, UK, 1997.

42. Geletkanycz, M.A.; Hambrick, D.C. The External Ties of Top Executives: Implications for Strategic Choice and Performance. Adm. Sci. Q. 1997, 42, 654-681. [CrossRef]

43. Eng, T.Y.; Liu, G.Y.G.; Sekhon, Y.K. The Role of Relationally Embedded Network Ties in Resource Acquisition of British Nonprofit Organizations. Nonprofit Volunt. Sect. Q. 2011, 41, 1092-1115. [CrossRef]

44. Chiliza, J.; Laing, R.; Feeley, F.G.; Borba, C.P.C. Program sustainability post PEPFAR direct service support in the Western Cape, South Africa. PLoS ONE 2021, 16, e0251230. [CrossRef]

45. Frumkin, P.; Andre-Clark, A. When missions, markets and politics collide: Values and strategy in the nonprofit human services. Nonprofit Volunt. Sect. Q. 2000, 29, 141-163. [CrossRef]

46. Jeuvons, T.H. When management is the message Relating values to management practice in nonprofit organizations. Nonprofit Manag. Leadersh. 1992, 2, 403-417. [CrossRef]

47. Bhamra, R.; Dani, S.; Burnard, K. Resilience: The concept, a literature review and future directions. Int. J. Prod. Res. 2011, 49, 5375-5393. [CrossRef]

48. Witmer, H.; Mellinger, M.S. Organizational resilience: Nonprofit organizations' response to change. Work 2016, 54, 255-265 [CrossRef]

49. Lee, H.L.; Tang, C.S. Socially and Environmentally Responsible Value Chain Innovations: New Operations Management Research Opportunities. Manag. Sci. 2018, 64, 983-996. [CrossRef]

50. Murry, J.W.; Hammons, J.O. Delphi: A versatile methodology for conducting qualitative research. Rev. High. Educ. 1995, 18, 423-436. [CrossRef]

51. Mahdavi, I.; Fazlollahtabar, H.; Heidarzade, A.; Mahdavi-Amiri, N.; Rooshan, Y.I. A Heuristic Methodology for Multi-Criteria Evaluation of Web-Based E-Learning Systems Based on User Satisfaction. J. Appl. Sci. 2008, 8, 4603-4609. [CrossRef]

52. Buckley, J.J. Fuzzy Hierarchical Analysis. Fuzzy Sets Syst. 1985, 17, 233-247. [CrossRef]

53. Evashwick, C.; Riedel, J. Managing Long-Term Care; Health Administration Press: Chicago, IL, USA, 2004.

54. Evashwick, C. The Continuum of Long-Term Care; Cengage Learning: Boston, MA, USA, 2005.

55. Vian, T.; Koseki, S.; Feeley, F.G.; Beard, J. Strengthening capacity for AIDS vaccine research: Analysis of the Pfizer Global Health Fellows Program and the International AIDS Vaccine Initiative. BMC Health Serv. Res. 2013, 13, 378. [CrossRef]

56. Claesson, M.; Jonasson, L.L.; Lindberg, E.; Josefsson, K. What implies registered nurses' leadership close to older adults in municipal home health care? A systematic review. BMC Nurs. 2020, 19, 30. [CrossRef]

57. Materla, T.; Cudney, E.A.; Antony, J. The application of Kano model in the healthcare industry: A systematic literature review. Total Qual. Manag. Bus. Excell. 2019, 30, 660-681. [CrossRef]

58. Golubeva, E.Y.; Khabarova, L.G. Family Care as a Tool for Mitigating the Social Risks of the Elderly People in Remote Areas. Adv. Gerontol. 2019, 9, 373-378. [CrossRef]

59. Allen, E.P.; Muhwezi, W.W.; Henriksson, D.K.; Mbonye, A.K. Health facility management and access: A qualitative analysis of challenges to seeking healthcare for children under five in Uganda. Health Policy Plan. 2017, 32, 934-942. [CrossRef] [PubMed]

60. Chen, Y.M.; Thompson, E.A.; Berkowitz, B.; Young, H.M.; Ward, D. Factors and Home- and Community-Based Services (HCBS) that Predict Older Adults' Residential Transitions. J. Serv. Sci. Manag. 2011, 4, 368-379. [CrossRef]

61. Balser, D.; McClusky, J. Managing Stakeholder Relationships and Nonprofit Organization Effectiveness. Nonprofit Manag. Leadersh. 2005, 15, 295-315. [CrossRef]

62. Lu, J. Which nonprofit gets more government funding? Nonprofits' organizational attributes and their receipts of government funding. Nonprofit Manag. Leadersh. 2015, 25, 297-312. [CrossRef]

63. Gilchrist, A. The Well-Connected Community: A Networking Approach to Community Development; Policy Press: Bristol, UK, 2004.

64. Salamon, L.M.; Anheier, H.K. Defining the Nonprofit Sector: Across-National Analysis; Manchester University Press: Manchester, UK, 1997.

65. Zhu, J.; Ye, S.; Liu, Y. Legitimacy, Board Involvement, and Resource Competitiveness: Drivers of NGO Revenue Diversification. Int. J. Volunt. Nonprofit Organ. 2018, 29, 1176-1189. [CrossRef]

66. Mirońska, D.; Zaborek, P. NGO-Business Collaboration: A Comparison of Organizational, Social, and Reputation Value From the NGO Perspective in Poland. Nonprofit Volunt. Sect. Q. 2019, 48, 532-551. [CrossRef]

67. Chang, S.S. Fuzzy Multi-Criteria Decision Making for Evaluation Method; Wu-Nan Book Inc.: Taipei, Taiwan, 2012. 
68. Ikram, M.; Zhang, Q.; Sroufe, R.; Ferasso, M. The Social Dimensions of Corporate Sustainability: An Integrative Framework Including COVID-19 Insights. Sustainability 2020, 12, 8747. [CrossRef]

69. Shah, S.A.A.; Solangi, Y.A.; Ikram, M. Analysis of barriers to the adoption of cleaner energy technologies in Pakistan using Modified Delphi and Fuzzy Analytical Hierarchy Process. J. Clean. Prod. 2019, 235, 1037-1050. [CrossRef]

70. Saaty, T.L. Analytic Hierarchy Process. Encyclopedia of Biostatistics; John Wiley \& Sons: Hoboken, NJ, USA, 1980.

71. Lipe, M.S.; Salterio, S.E. The Balanced Scorecard: Judgmental Effects of Common and Unique Performance Measures. Account. Rev. 2000, 75, 283-298. [CrossRef]

72. Folke, C. Resilience: The emergence of a perspective for social-ecological systems analyses. Glob. Environ. Chang. 2006, 16, 253-267. [CrossRef] 